\title{
Diet of Peregrine Falcons (Falco peregrinus) in relation to temporal and spatial variation in racing pigeon availability in Wales
}

\author{
Andrew Dixon*, Colin Richards \& Andrew KIng
}

Received: October 30, 2018 -Revised: December 03, 2018 -Accepted: December 21, 2018

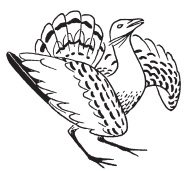

Dixon, A., Richards, C. \& King, A. 2018. Diet of Peregrine Falcons (Falco peregrinus) in relation to temporal and spatial variation in racing pigeon availability in Wales. - Ornis Hungarica 26(2): 188-200. DOI: 10.1515/orhu-2018-0028

Falcons differed across three areas of south-central Wales in line with racing pigeon availability. Peregrines exhibited a functional response to spatial and temporal availability of racing pigeons. During the pigeon-racing season (April-September), pigeons comprised 63\% of kills in South Wales where pigeons were most available, $43 \%$ in the Brecon Beacons with intermediate availability and 30\% in Central Wales, where availability was lowest. The corresponding values outside the pigeon-racing season were $18 \%, 6 \%$ and $5 \%$ respectively. We estimate that $92 \%$ of pigeons killed by Peregrines were racing pigeons, $7 \%$ were feral pigeons and the remainder were other domestic pigeon varieties.

Keywords: Columba livia, predator-prey, functional response, human-wildlife conflict

Összefoglalás A vándorsólyom étrendjében három dél-közép-walesi területen eltérést mutat a parlagi/házi galamb Columba livia hozzávetőleges gyakorisága, összefüggésben a galambászok által tenyésztett példányok elérhetőségével. A vándorsólymok funkcionális választ mutatnak az ilyen galambok térbeli és időbeli elérhetőségére. A galamb-versenyek időszakában (április-szeptember) Dél-Walesben, ahol a versenyekre tenyésztett galambok száma a legmagasabb, az elejtett prédák 63\%-a volt galamb, Brecon Beacons térségében 43\%, míg ahol a legkevesebb ilyen galamb volt (Közép-Wales), csupán 30\% volt ez az arány. Ugyanezen területeken a versenyidőszakon kívül az arányok $18 \%, 6 \%$ és 5\% körül alakultak. Felméréseink alapján elmondható, hogy az elejtett galambok $92 \%$-át versenyekre tenyésztették, 7\%-a vadon élő volt, a többi pedig más, háziasított formákból származott.

Kulcsszavak: Columba livia, ragadozó-préda, funkcionális válasz, ember és vadon élő állatok közti konfliktus

South Wales Peregrine Monitoring Group, clo 96 Yr Ysfa, Maesteg, Bridgend, Glamorgan CF34 9BE, UK

*corresponding author,e-mail: adixonwales@gmail.com

\section{Introduction}

In the United Kingdom, Common Pigeons Columba livia comprise a significant proportion of the Peregrine diet in many regions (Ratcliffe 1993, Drewitt \& Dixon 2008). Ratcliffe (1993) proposed that high Peregrine breeding densities found in Snowdonia, Lakeland and Galloway reflected the large, but seasonal supply of racing pigeons that pass through these areas. In South Wales, it has been suggested that Peregrines are largely dependent on racing pigeons for successful breeding (Richards \& Shrubb 1999). Euphemistically described as 'domestic' or 'feral', the pigeons killed by Peregrines comprise mostly racing pigeons (Dixon \& Richards 2003, Dixon et al. 2003, Parrott et al. 2008), to the extent that changes in 
racing pigeon availability is considered a causal factor of Peregrine population changes in some UK regions (Dixon et al. 2010, Wilson et al. 2018). While the influence of racing pigeons on Peregrine ecology is of interest to ornithologists, the potential impact of Peregrine predation on racing pigeons is of concern to pigeon racing enthusiasts (Scottish Homing Union 1998), creating a human-wildlife conflict (Shawyer et al. 2000, Dixon 2002, Henderson et al. 2004).

Common Pigeons exist in various forms and most studies on the diet of Peregrines do not distinguish between them. There is the 'wild-type', the Rock Dove, which has a very restricted range in Britain as a result of inter-breeding with domesticated varieties (Gibbons et al. 1993). Rock Doves have largely been replaced by 'feral pigeons', most of which are wild-bred rather than captive-bred pigeons living a feral existence (Shawyer et al. 2000). Feral pigeons have a predominantly coastal and urban distribution, though there is some evidence of an expansion into rural arable areas (Gibbons et al. 1993). Captive-bred varieties of Common Pigeon, can often be identified by leg-rings and are kept as decorative pets in dovecotes or as sporting pigeons in the form of racers, show-pigeons, tipplers and rollers; the most abundant of these various 'domestic pigeons' is the racing pigeon. Racing pigeons can occur either on passage or as strays in most areas of Britain during the race season (April-September) and home lofts are widespread with concentrations in certain areas.

In this paper we describe the diet of Peregrines inhabiting south-central Wales, focussing particularly on spatial and temporal variation in the availability of racing pigeons. We also examine spatial variation in the 'home origin' of racing pigeons killed at a regional level in south-central Wales and at a finer local scale within South Wales.

\section{Materials and methods}

\section{Study area}

Peregrine sites within our south-central Wales study region were allocated to three areas i.e. South Wales, the Brecon Beacons and Central Wales (Figure 1). The South Wales area is the main centre of pigeon racing in Wales and holds approximately 2350 racing pigeon lofts distributed across most of

Figure 1. Map showing the division of south-central Wales into three regions; Central Wales (CW), Brecon Beacons (BB) and South Wales (SW). Grey circles mark Peregrine breeding sites and triangles show the location of racing pigeon clubs

1.ábra Dél-Közép-Wales területi felosztásának térképe: Közép-Wales (CW), Brecon Beacons (BB) és Dél-Wales (SW). A szürke körök a vándorsólymok költőhelyeit, a háromszögek a sportgalambász egyesületek elhelyezkedését jelölik

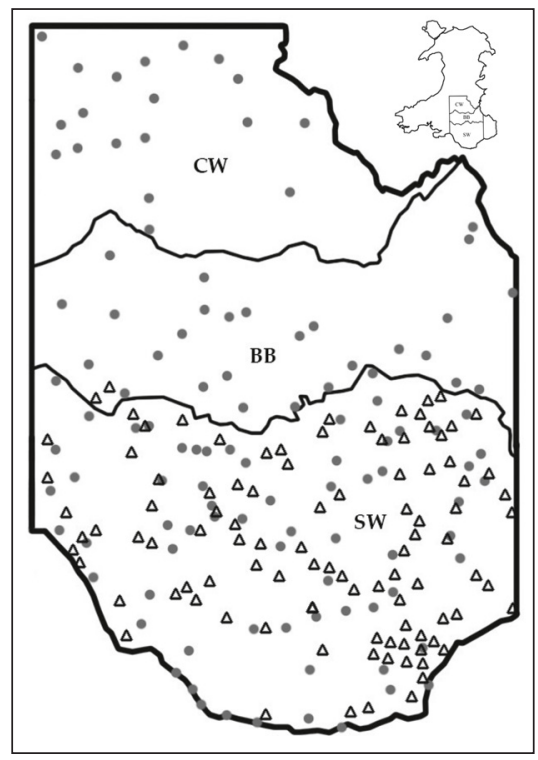


the valley towns. Individual lofts in a local area are organised into clubs; the distribution of these local clubs in south-central Wales is shown in Figure 1. The Brecon Beacons area includes Peregrine breeding sites within the boundary of the Brecon Beacons National Park. The Brecon Beacons area holds few pigeon lofts (probably less than 50). The Central Wales area lies to the north of the Brecon Beacons National Park and holds very few racing pigeon lofts (probably less than 10).

\section{Racing pigeon availability}

The racing pigeon population in Britain varies in time and space which makes quantitative assessment difficult. The abundance of racing pigeons not only varies seasonally between the race season and the off-season, but also within the race season on a daily basis because most races take place on weekends. In addition to this temporal variation, the abundance of racing pigeons varies spatially depending on the geographical location of lofts, training routes and race routes. Nevertheless, it is still possible to make a qualitative assessment of their availability as prey for Peregrines. The availability of pigeons as prey is related to their activity. We have designated four activities to describe the circumstances of racing pigeons that are available as prey for Peregrines. (1) Pigeons on race flights, (2) pigeons on training flights, (3) pigeons exercising around the loft and (4) stray pigeons that have failed to return to lofts. The availability of racing pigeons in each of these four classes differed between study areas (Table 1).

Pigeons on race flights are normally only available on weekends along routes between the liberation point and the home loft. Race distances vary in length and pigeons can deviate significantly from a direct flight route yet still home successfully (Dall 'Antonia et al. 1999). Thus, pigeons on races have an ephemeral, but potentially very widespread, availability. Training flights are of shorter length and occur more frequently than races, but are normally conducted at the same bearing from the home loft. Thus, pigeons on training flights have more frequent but less widespread availability than pigeons on races. During the race season, pigeons are normally released daily from their lofts for exercise flights in the local area. Pigeons on exercise flights have a very frequent but spatially restricted availability. Finally, stray racing pigeons can potentially occur anywhere at any time, though their availability may vary both in time and space. It is likely that there are more strays in the environment immediately following a race weekend and that some of these birds eventually make their way home. Furthermore, it is possible that strays are attracted

Table 1. Qualitative assessment of the availability of racing pigeons as prey within three study areas of south-central Wales

1. táblázat Minőségi értékelés a versenyzésre tenyésztett galambok, mint prédaállatok elérhetőségéről a három vizsgálati területen, Dél-Közép-Walesben

\begin{tabular}{|l|c|c|}
\hline \multicolumn{1}{|c|}{ Study Region } & Pigeon Availability & Circumstance of Availability \\
\hline South Wales & Highest & Exercising : Training : Racing : Stray \\
\hline Brecon Beacons & Intermediate & Training: Racing: Stray \\
\hline Central Wales & Lowest & Racing: Stray \\
\hline
\end{tabular}


to particular areas, perhaps to localities where there are large aggregations of lofts or arable areas with a rich food supply. We had no means of assessing the relative availability of stray pigeons between our study areas, but we believe that they were more abundant in South Wales, possibly having been attracted to the area by resident pigeons returning home from races.

\section{Peregrine diet}

Over the period 1985-2018, we identified the remains of avian prey at Peregrine breeding ranges in south-central Wales. Prey remains consisted of plucked feathers and partially eaten carcasses. In most cases, in the absence of whole or partially eaten carcases, we categorized the remains based on the condition and number of feathers found at plucking sites, judging them to be either 'recent kills' allocated to the month when they were found or else killed within one of two seasons, 'summer' (April-September; corresponding with the timing of the pigeon race season in Britain) or 'winter' (October-March). Avian prey remains that could not be allocated to a particular month or season were not included in our analyses.

The use of prey remains to characterise raptor diets has a number of potential biases (e.g. Newton \& Marquiss 1982). However, as we are only using prey remains to compare the relative frequency of prey species between study areas our approach should not be biased in any particular direction. In order to account for variation in sampling effort, for major prey species, we calculated their percentage of total prey items in each month of the year.

\section{Results}

\section{Diet of Peregrines in south-central Wales}

We identified 95 species killed by Peregrines in our study areas (Appendix 1), including three that could not be assigned to a specific season i.e. Manx Shearwater Puffinus puffinus, Sandwich Tern Thalasseus sandvicensis and Canary Serinus canaria (the former two being vagrants in south-central Wales and the latter an escaped exotic). In South Wales we identified 79 species from 2869 prey remains, in the Brecon Beacons 60 species from 1215 prey remains and in Central Wales 61 species from 922 prey remains. Common Pigeons were the most important prey species in all three study areas. Apart from Common Pigeons, Jackdaws Coloeus monedula, were frequently killed throughout the year, comprising more than $5 \%$ of prey by frequency and weight in summer and winter across all three study areas. Starlings were also an important prey species, comprising more than $5 \%$ of prey by frequency in both seasons in each study area. In winter across all three study areas, Wood Pigeons Columba palumbus and Woodcock Scolopax rusticola comprised more than 5\% of prey by weight, while Fieldfare Turdus pilaris, Redwing T. iliacus and Blackbird T. merula comprised more than $5 \%$ of prey by frequency. 


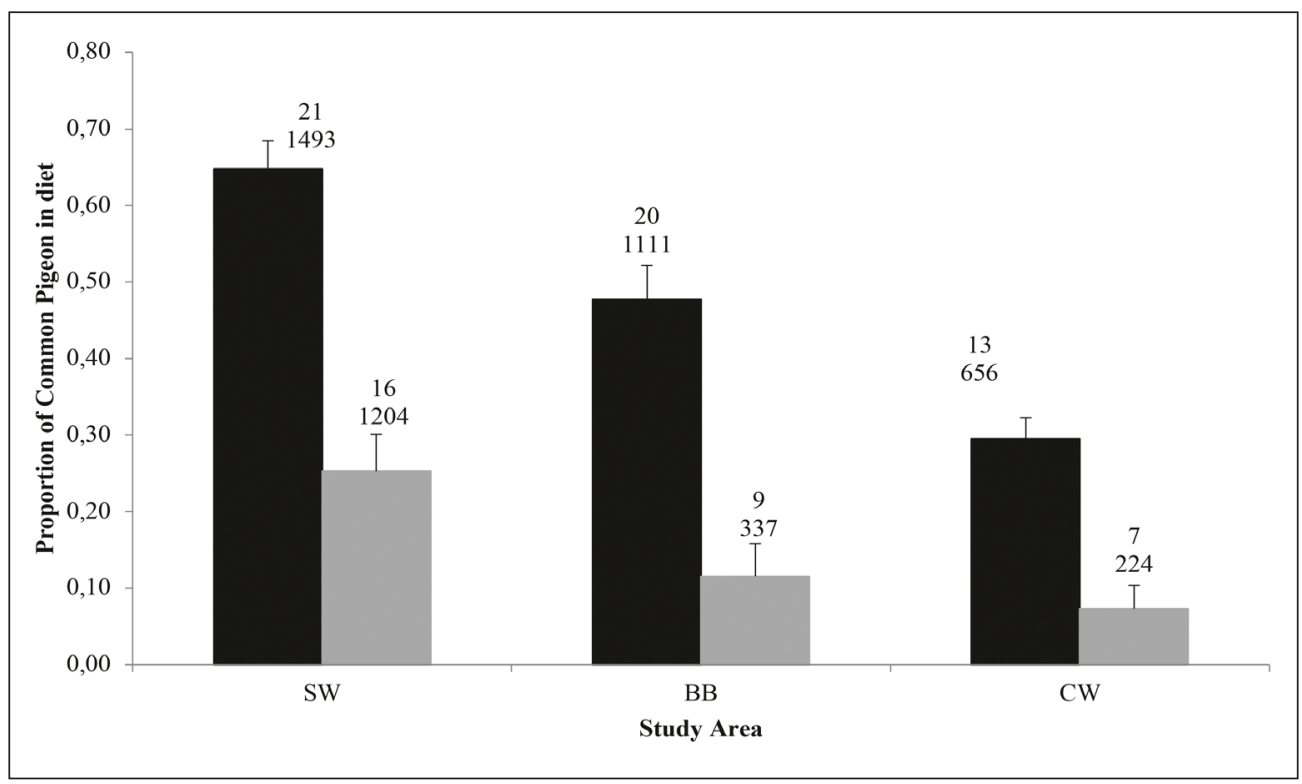

Figure 2. Proportion of Common Pigeons in the diet of Peregrines in each of the three study areas ( $\mathrm{SW}=$ South Wales, $\mathrm{BB}=$ Brecon Beacons, $\mathrm{CW}=$ Central Wales). Black columns represent summer period and grey columns winter period. Values above SE bars refer to the number of Peregrine territories sampled and the number of prey items identified

2.ábra A parlagi/házi galamb gyakoriság a vándorsólymok étrendjében a három vizsgálati területen (SW = Dél-Wales, BB = Brecon Beacons, $C W=$ Közép-Wales). A fekete oszlopok a nyári, a szürkék pedig a téli időszakot jelentik. A hibaértékeket jelölő sávok fölötti értékek a vizsgált vándorsólyom territóriumok számát és az azonosított prédák számát mutatják

The frequency of Common Pigeons in prey remains in south-central Wales varied significantly throughout the year. Pigeons are killed much more frequently during the pigeon race season than outside it (Fisher's exact test $P<0.0001$ ), highlighting the importance of racing pigeons in the diet. During the pigeon race season, there was a significant difference in the frequency of pigeons killed in South Wales (63\% of kills), the Brecon Beacons (43\%) and Central Wales $\left(30 \% ; \chi^{2}=238,2 d f, P<0.00001\right)$ (Figure 2). In terms of prey mass the corresponding percentages were $84 \%, 67 \%$ and $50 \%$ respectively. Outside the pigeon race season, the frequency of common pigeons killed was lower overall, but still significantly higher in South Wales (18\% of kills), than the Brecon Beacons $(6 \%)$ and Central Wales $\left(5 \% ; \chi^{2}\right.$ $=57,2 d f, P<0.00001$ ) (Figure 2); in terms of prey mass, the corresponding percentages were $38 \%, 14 \%$ and $14 \%$ respectively.

The proportion of Common Pigeons in the diet increased and decreased sharply in April and September respectively (Figure $3 a$ ). The proportion of Jackdaws in the diet ranged from $5 \%$ to $17 \%$ of monthly prey items (Figure 3 b), Starlings were killed most frequently in June and during the winter months (Figure 3c). Fieldfare and Redwing appeared in the diet in October, peaked in December and were last found among prey remains in May (Figure 3d) and the proportion of Woodcock in the diet exhibited a similar pattern (Figure 3e). 


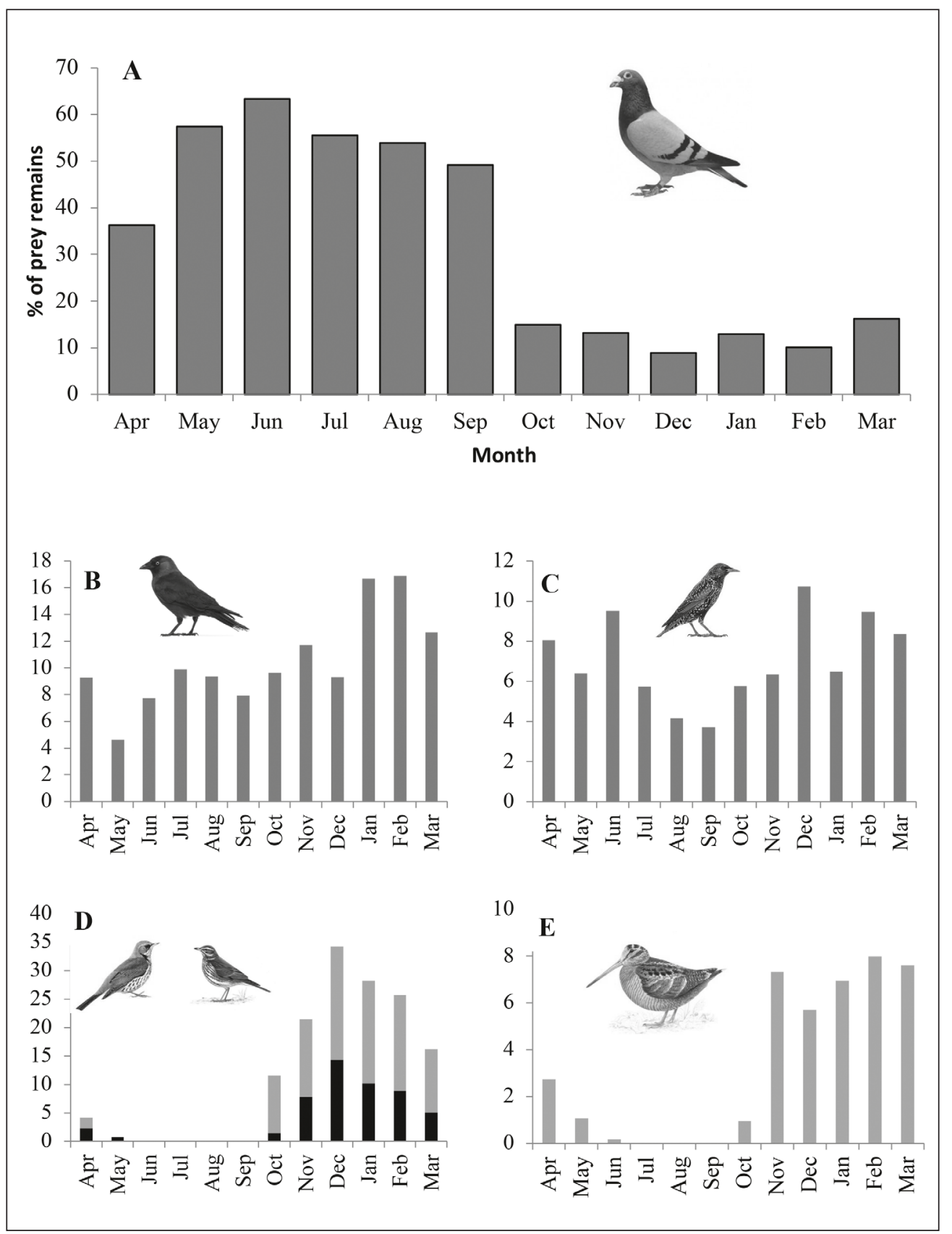

Figure 3. Proportion of Common Pigeon (A), Jackdaw (B), Starling (C), Fieldfare (black column) and Redwing (grey column) (D) and Woodcock (E) in the diet during each month of the year across south-central Wales

3. ábra. A parlagi/házi galamb (A), a csóka (B), a seregély (C), a fenyőrigó (fekete oszlop) és a szőlőrigó (szürke oszlop) (D), valamint a szalonka (E) aránya a vándorsólymok táplálékában hónapokra lebontva, Dél-Közép-Wales területén 


\section{Types of Common Pigeon killed by Peregrines}

Of 30 Common Pigeon carcasses with both legs present, 28 were ringed indicating that in south-central Wales nearly 7\% of pigeon kills were 'feral pigeons' and 93\% were domestic pigeons. All but two of these carcasses, both of which were ringed domestic pigeons, were found during the pigeon race season and both feral pigeons were found at Peregrine sites in South Wales.

In a sample of 5049 domestic pigeon rings collected at Peregrine sites in south-central Wales $98.7 \%(\mathrm{~N}=4984)$ were from racing pigeons, $0.8 \%(n=40)$ were from tipplers, $0.3 \%$ $(n=15)$ were rollers, $0.2 \%(n=10)$ were show pigeons. Most tippler rings were recovered from Peregrine nesting sites in the Swansea, Neath and Port Talbot districts $(73 \%)$.

\section{Discussion}

\section{Diet of Peregrines in south-central Wales}

The diet of Peregrines in south-central Wales varied in line with spatial and temporal variation in the availability of racing pigeons: where and when racing pigeons were most available they comprised a greater proportion of the diet. Peregrines respond to changes in relative availability of racing pigeons and thus behave like opportunistic generalist avian predators, but it remains an unanswered question as to whether Peregrines selectively specialized on racing pigeons (e.g. Dawson et al. 2011). Fixation by Peregrines on particular prey species may lead to increased skill in capture, while certain species may be particularly vulnerable prey because of their mass, flight behaviour and their occurrence in unfamiliar habitats (White et al. 2002). Racing pigeons, with a typical mass of $435 \mathrm{~g}$ (Irvine et al. 2007), fall within the range of 50-500 g suggested to represent optimal prey mass for Peregrines (Ratcliffe 1993, White et al. 2002) and are selectively bred to home accurately and rapidly, and thus are unlikely to exhibit the range of predator avoidance strategies found in wild birds, or find refuges from attack when in unfamiliar habitats on long distance races or if they have strayed from the loft region.

Despite the wide range of prey species killed by Peregrines, the main part of the diet in south-central Wales comprises a relatively small number of species. In summer, in Central Wales where racing pigeons are less available, corvids are an important component of the diet, particularly Jackdaws but also Magpie Pica pica and Rook Corvus frugilegus, along with Wood Pigeon, Mistle Thrush Turdus viscivorus and Starling. In winter, when racing pigeons are less available across all regions, the same species are important with the addition of species that winter in south-central Wales, especially migratory thrushes such as Fieldfare, Redwing and Blackbird, along with Woodcock.

The monthly proportion of Common Pigeons in the diet varied in line with the timing of the pigeon race season, as would be expected when most Common Pigeons killed are racing pigeons. Jackdaws are the next most important prey species for Peregrines in south-central Wales, killed in relatively consistent proportions across the year. Starlings were killed 
most frequently in June when post-fledging summer flocks were formed and during winter when resident flocks were augmented by winter migrants. Migrant thrushes and Woodcock are important prey species that arrive in south-central Wales at the end of the pigeon season and make up, at least partially, for the loss of racing pigeon biomass from the environment.

\section{Types of Common Pigeon killed by Peregrines}

There is little arable land in any of our three study areas to attract roving flocks of feral pigeons, thus their distribution is mainly restricted to human settlements. Feral pigeons are abundant in most of the larger towns throughout South Wales (Tyler et al. 1987, Hurford \& Lansdown 1995). They are less abundant in the Brecon Beacons and Central Wales, but they do occur in many of the larger towns within these regions (Gibbons et al. 1993). Most of the Common Pigeons killed were racing pigeons, though there were a few other varieties of domestic pigeon represented in our ring sample, mainly tipplers, rollers and show pigeons. Their occurrence was highly localised to Peregrine sites in the Swansea, Neath and Port Talbot districts. Tippler pigeons, whose purpose is to fly high above the loft for long periods, must be particularly susceptible to predation. Musgrove (1994) reported that in Bristol, tippler flying all but ceased following colonisation of the city by Peregrines. We note that a similar decline in tippler flying in the Swansea area was reflected in the decreasing frequency of tippler rings recovered from local Peregrine sites over time (tipplers comprised 1.3\% of domestic pigeons ringed between 1992-1996 and only 0.5\% that were ringed between 1997-2001).

\section{Acknowledgements}

We thank M. S. Thomas, M. Warburton, G. Roberts, A. M. Lawrence, A. Lowe, P. Haffield for assistance in the field.

\section{References}

Dall 'Antonia, P., Dall 'Antonia, L., Ribolini, A., Ioale, P. \& Benvenuti, S. 1999. Pigeon homing: site simulation experiments with bird-borne detection recorders. - Behavioural Processes 44: 331-339. DOI: 10.1016/S0376-6357(98)00054-0

Dawson, R. D., Mossop, D. H. \& Boukall, B. 2011. Prey use and selection in relation to reproduction by Peregrine Falcons breeding along the Yukon River, Canada. - Journal of Raptor Research 45: 27-37. DOI: 10.3356/JRR-09-84.1

Dixon, A. 2002. Attacks by birds of prey on racing pigeons. - Report for the Confederation of Long Distance Racing Pigeon Unions of Great Britain and Ireland, Lancaster University

Dixon, A. \& Richards, C. 2003. Estimating the number of racing pigeons killed at Peregrine (Falco peregrinus) territories in South Wales. - Welsh Birds 3: 344-353.

Dixon, A., Richards, C., Lawrence, A. \& Thomas, M. 2003. Peregrine (Falco peregrinus) predation on Racing Pigeons (Columba livia) in Wales. - In: Thompson, D. B. A., Redpath, S. M., Fielding, A. H., Marquiss, M. \& Galbraith, C. A. (eds.) Birds of Prey in a Changing Environment. - The Stationary Office, Edinburgh, pp. 255-261.

Dixon, A., Richards, C., Haffield, P., Thomas, M., Lawrence, M. \& Roberts, G. 2010. Population decline of Peregrines Falco peregrinus in central Wales associated with a reduction in racing pigeon availability. Birds in Wales 7: 3-12. 
Drewitt, E. J. A. \& Dixon, N. 2008. Diet and prey selection of urban-dwelling Peregrine Falcons in southwest England. - British Birds 101: 58-67.

Gibbons, D. W., Reid, J. B. \& Chapman, R. A. 1993. The New Atlas of Breeding Birds in Britain and Ireland: 1988-1991. - T \& AD Poyser, London

Henderson, I., Parrott, D. \& Moore, N. 2004. Racing Pigeons - Impact of Raptor Predation. - Central Science Laboratory report to Scottish Natural Heritage \& Scottish Homing Union

Hurford, C. \& Lansdown, P. 1995. Birds of Glamorgan. - National Museum of Wales, Cardiff

Irvine, R. J., Leckie, F. \& Redpath, S. M. 2007. Cost of carrying radio transmitters: a test with racing pigeons Columba livia. - Wildlife Biology 13: 238-243. DOI: 10.2981/0909-6396(2007)13[238:COCRTA]2.0. $\mathrm{CO} ; 2$

Musgrove, A. 1994. Peregrines and Pigeons: investigations into a raptor-human conflict. - Unpublished PhD thesis, University of Bristol

Newton, I. \& Marquiss, M. 1982. Food, predation and breeding season in Sparrowhawks Accipiter nisus. Journal of the Zoological Society of London 197: 221-240. DOI: 10.1111/jzo.1982.197.2.221

Parrott, D., Henderson, I., Deppe, C. \& Whitfield, P. 2008. Scottish racing pigeons killed by Peregrine Falcons Falco peregrinus: estimation of numbers from ring recoveries and Peregrine daily food intake. - Bird Study 55: 32-42. DOI: 10.1080/00063650809461502

Ratcliffe, D. 1993. The Peregrine Falcon. Second Edition. - T \& AD Poyser, London

Richards, C. \& Shrubb, M. 1999. The prey of Peregrines Falco peregrinus in South Wales. - Welsh Birds 3: $131-136$.

Scottish Homing Union 1998. Attacks by Peregrines and Sparrowhawks on Racing Pigeons in Scotland. SHU, Hamilton

Shawyer, C., Clarke, R. \& Dixon, N. 2000. A Study into the Raptor Predation of Domestic Pigeons. - DETR, London

Tyler, S., Lewis, J., Venables, A. \& Walton, J. 1987. The Gwent Atlas of Breeding Birds. - Gwent Ornithological Society, Newport

White, C. M., Clum, N. J., Cade, T. J. \& Hunt, W. G. 2002. Peregrine Falcon (Falco pereginus). - In: Poole, A. \& Gill, F (eds.) The Birds of North America, No. 660. -. The Birds of North America Inc., Philadelphia, USA

Wilson, M. W., Balmer, D. E., Jones, K., King, V. A., Raw, D., Rollie, C. J., Rooney, E., Ruddock, M., Smith, G. D., Stevenson, A., Stirling-Aird, P. K., Wernham, C. V., Weston, J. M. \& Noble, D. G. 2018. The breeding population of Peregrine Falcon Falco peregrinus in the United Kingdom, Isle of Man and Channel Islands in 2014. - Bird Study 65: 1-19. 
Appendix 1. Prey species identified at Peregrine breeding sites in the Central Wales, Brecon Beacons and South Wales study areas during summer (April-September) and winter (OctoberMarch). \% $\mathrm{N}$ is the percentage of prey items by frequency ( $\mathrm{N}=$ number of prey items) and $\% \mathrm{wt}$. is the percentage of total prey mass for each species

1. függelék Azonosított prédafajok a vándorsólyom költőhelyeken a közép-walesi, Brecon Beaconsi és dél-walesi vizsgálati területeken a nyári (április-szeptember) és téli (október-március) időszak alatt. A \% N a zsákmányállatok aránya gyakoriság szerint ( $\mathrm{N}$ = zsákmányállatok száma), a \% wt. pedig a teljes zsákmány tömegének százalékos aránya minden fajra

\begin{tabular}{|c|c|c|c|c|c|c|c|c|c|c|c|c|}
\hline \multirow{3}{*}{ Species } & \multicolumn{4}{|c|}{ Central Wales } & \multicolumn{4}{|c|}{ Brecon Beacons } & \multicolumn{4}{|c|}{ South Wales } \\
\hline & \multicolumn{2}{|c|}{ Summer } & \multicolumn{2}{|c|}{ Winter } & \multicolumn{2}{|c|}{ Summer } & \multicolumn{2}{|c|}{ Winter } & \multicolumn{2}{|c|}{ Summer } & \multicolumn{2}{|c|}{ Winter } \\
\hline & $\% \mathrm{~N}(\mathrm{~N})$ & $\begin{array}{r}\% \\
\text { wt. }\end{array}$ & $\% \mathrm{~N}(\mathrm{~N})$ & \begin{tabular}{|c|}
$\%$ \\
wt.
\end{tabular} & $\% \mathrm{~N}(\mathrm{~N})$ & \begin{tabular}{|c|}
$\%$ \\
wt.
\end{tabular} & $\% \mathrm{~N}(\mathrm{~N})$ & \begin{tabular}{|c|}
$\%$ \\
wt.
\end{tabular} & $\% \mathrm{~N}(\mathrm{~N})$ & \begin{tabular}{|c|}
$\%$ \\
wt.
\end{tabular} & $\% \mathbf{N}(\mathrm{N})$ & $\begin{array}{r}\% \\
\text { wt. }\end{array}$ \\
\hline $\begin{array}{l}\text { Willow Grouse } \\
\text { Lagopus lagopus }\end{array}$ & $0.2(1)$ & 0.4 & $0.0(0)$ & 0.0 & $0.1(1)$ & 0.3 & $0.5(2)$ & 1.6 & $0.0(0)$ & 0.0 & $0.0(0)$ & 0.0 \\
\hline $\begin{array}{l}\text { Red-legged Partridge } \\
\text { Alectoris rufa }\end{array}$ & $0.0(0)$ & 0.0 & $0.4(1)$ & 1.2 & $0.0(0)$ & 0.0 & $0.0(0)$ & 0.0 & $0.1(1)$ & 0.1 & $0.0(0)$ & 0.0 \\
\hline $\begin{array}{l}\text { Pheasant } \\
\text { Phasianus colchicus }\end{array}$ & $0.2(1)$ & 0.7 & $0.4(1)$ & 2.9 & $0.0(0)$ & 0.0 & $0.0(0)$ & 0.0 & $0.0(0)$ & 0.0 & $0.1(1)$ & 0.4 \\
\hline $\begin{array}{l}\text { Mallard } \\
\text { Anas platyrhynchos }\end{array}$ & $0.3(2)$ & 1.2 & $0.0(0)$ & 0.0 & $0.1(1)$ & 0.5 & $0.0(0)$ & 0.0 & $0.1(1)$ & 0.2 & $0.2(3)$ & 1.2 \\
\hline $\begin{array}{l}\text { Teal } \\
\text { Anas crecca }\end{array}$ & $0.3(2)$ & 0.4 & $1.5(4)$ & 3.2 & $0.1(1)$ & 0.1 & $0.7(3)$ & 1.3 & $0.0(0)$ & 0.0 & $0.2(2)$ & 0.2 \\
\hline $\begin{array}{l}\text { Tufted Duck } \\
\text { Aythya fuligula }\end{array}$ & $0.0(0)$ & 0.0 & $0.0(0)$ & 0.0 & $0.0(0)$ & 0.0 & $0.0(0)$ & 0.0 & $0.0(0)$ & 0.0 & $0.1(1)$ & 0.3 \\
\hline $\begin{array}{l}\text { Common Pigeon } \\
\text { Columba livia }\end{array}$ & $\begin{array}{l}29.5 \\
(195)\end{array}$ & 50.4 & $5.0(13)$ & 13.7 & $\begin{array}{l}42.5 \\
(328) \\
\end{array}$ & 67.1 & $5.8(24)$ & 13.9 & $\begin{array}{c}63.2 \\
(1005) \\
\end{array}$ & 83.9 & $\begin{array}{l}17.9 \\
(228)\end{array}$ & 37.7 \\
\hline $\begin{array}{l}\text { Stock Dove } \\
\text { Columba oenas }\end{array}$ & $0.0(0)$ & 0.0 & $0.4(1)$ & 0.7 & $0.0(0)$ & 0.0 & $0.0(0)$ & 0.0 & $0.1(1)$ & 0.1 & $0.2(3)$ & 0.3 \\
\hline $\begin{array}{l}\text { Wood Pigeon } \\
\text { Columba palumbus }\end{array}$ & $4.2(28)$ & 7.5 & $2.7(7)$ & 7.7 & $2.0(16)$ & 3.3 & $2.4(10)$ & 6.0 & $1.8(29)$ & 2.5 & $3.9(50)$ & 8.5 \\
\hline $\begin{array}{l}\text { Collared Dove } \\
\text { Streptopelia decaocto }\end{array}$ & $0.2(1)$ & 0.1 & $0.4(1)$ & 0.5 & $0.3(2)$ & 0.2 & $0.2(1)$ & 0.3 & $0.3(4)$ & 0.2 & $0.5(6)$ & 0.5 \\
\hline $\begin{array}{l}\text { Common Swift } \\
\text { Apus apus }\end{array}$ & $1.4(9)$ & 0.2 & $0.0(0)$ & 0.0 & $0.9(7)$ & 0.1 & $0.0(0)$ & 0.0 & $0.6(9)$ & 0.1 & $0.0(0)$ & 0.0 \\
\hline $\begin{array}{l}\text { Common Cuckoo } \\
\text { Cuculus canorus }\end{array}$ & $0.5(3)$ & 0.2 & $0.0(0)$ & 0.0 & $0.3(2)$ & 0.1 & $0.0(0)$ & 0.0 & $0.3(4)$ & 0.1 & $0.0(0)$ & 0.0 \\
\hline $\begin{array}{l}\text { Eurasian Coot } \\
\text { Fulica atra }\end{array}$ & $0.2(1)$ & 0.5 & $0.0(0)$ & 0.0 & $0.0(0)$ & 0.0 & $0.0(0)$ & 0.0 & $0.0(0)$ & 0.0 & $0.0(0)$ & 0.0 \\
\hline $\begin{array}{l}\text { Grey Heron } \\
\text { Ardea cinerea }\end{array}$ & $0.0(0)$ & 0.0 & $0.0(0)$ & 0.0 & $0.1(1)$ & 0.7 & $0.0(0)$ & 0.0 & $0.0(0)$ & 0.0 & $0.0(0)$ & 0.0 \\
\hline $\begin{array}{l}\text { Oystercatcher } \\
\text { Haematopus ostralegus }\end{array}$ & $0.0(0)$ & 0.0 & $0.4(1)$ & 1.3 & $0.0(0)$ & 0.0 & $0.0(0)$ & 0.0 & $0.0(0)$ & 0.0 & $0.0(0)$ & 0.0 \\
\hline $\begin{array}{l}\text { Lapwing } \\
\text { Vanellus vanellus }\end{array}$ & $0.6(4)$ & 0.5 & $0.0(0)$ & 0.0 & $0.4(3)$ & 0.3 & $1.2(5)$ & 1.5 & $0.3(5)$ & 0.2 & $0.9(11)$ & 1.0 \\
\hline $\begin{array}{l}\text { Golden Plover } \\
\text { Pluvialis apricaria }\end{array}$ & $1.5(10)$ & 1.3 & $1.9(5)$ & 2.7 & $0.0(0)$ & 0.0 & $1.2(5)$ & 1.5 & $0.1(1)$ & $<0.1$ & $1.2(15)$ & 1.2 \\
\hline $\begin{array}{l}\text { Grey Plover } \\
\text { Pluvialis squatarola }\end{array}$ & $0.0(0)$ & 0.0 & $0.0(0)$ & 0.0 & $0.0(0)$ & 0.0 & $0.0(0)$ & 0.0 & $0.0(0)$ & 0.0 & $0.1(1)$ & 0.1 \\
\hline $\begin{array}{l}\text { Woodcock } \\
\text { Scolopax rusticola }\end{array}$ & $1.4(9)$ & 1.5 & $4.6(12)$ & 8.2 & $0.5(4)$ & 0.5 & $\begin{array}{l}7.7 \\
(32)\end{array}$ & 11.9 & $0.5(8)$ & 0.4 & $\begin{array}{l}6.1 \\
(78)\end{array}$ & 8.2 \\
\hline $\begin{array}{l}\text { Common Snipe } \\
\text { Gallinago gallinago }\end{array}$ & $0.8(5)$ & 0.3 & $0.4(1)$ & 0.3 & $0.4(3)$ & 0.2 & $1.7(7)$ & 1.0 & $0.2(3)$ & 0.1 & $1.9(24)$ & 1.0 \\
\hline $\begin{array}{l}\text { Curlew } \\
\text { Numenius arquata }\end{array}$ & $0.3(2)$ & 1.1 & $0.0(0)$ & 0.0 & $0.4(3)$ & 1.2 & $0.0(0)$ & 0.0 & $0.1(1)$ & 0.2 & $0.0(0)$ & 0.0 \\
\hline
\end{tabular}




\begin{tabular}{|c|c|c|c|c|c|c|c|c|c|c|c|c|}
\hline \multirow{3}{*}{ Species } & \multicolumn{4}{|c|}{ Central Wales } & \multicolumn{4}{|c|}{ Brecon Beacons } & \multicolumn{4}{|c|}{ South Wales } \\
\hline & \multicolumn{2}{|c|}{ Summer } & \multicolumn{2}{|c|}{ Winter } & \multicolumn{2}{|c|}{ Summer } & \multicolumn{2}{|c|}{ Winter } & \multicolumn{2}{|c|}{ Summer } & \multicolumn{2}{|c|}{ Winter } \\
\hline & $\% \mathbf{N}(\mathbf{N})$ & \begin{tabular}{c|}
$\%$ \\
wt.
\end{tabular} & $\% \mathrm{~N}(\mathrm{~N})$ & $\begin{array}{c}\% \\
\text { wt. }\end{array}$ & $\% \mathbf{N}(\mathbf{N})$ & $\begin{array}{c}\% \\
\text { wt. }\end{array}$ & $\% \mathrm{~N}(\mathrm{~N})$ & $\begin{array}{r}\% \\
\text { wt. }\end{array}$ & $\% \mathbf{N}(\mathbf{N})$ & \begin{tabular}{r|r}
$\%$ \\
wt.
\end{tabular} & $\% \mathbf{N}(\mathbf{N})$ & $\begin{array}{r}\% \\
\text { wt. }\end{array}$ \\
\hline $\begin{array}{l}\text { Common Redshank } \\
\text { Tringa totanus }\end{array}$ & $0.0(0)$ & 0.0 & $0.0(0)$ & 0.0 & $0.1(1)$ & 0.1 & $0.0(0)$ & 0.0 & $0.0(0)$ & 0.0 & $0.0(0)$ & 0.0 \\
\hline $\begin{array}{l}\text { Greenshank } \\
\text { Tringa nebularia }\end{array}$ & $0.2(1)$ & 0.1 & $0.0(0)$ & 0.0 & $0.3(2)$ & 0.2 & $0.0(0)$ & 0.0 & $0.0(0)$ & 0.0 & $0.0(0)$ & 0.0 \\
\hline $\begin{array}{l}\text { Little Stint } \\
\text { Calidris minuta }\end{array}$ & $0.0(0)$ & 0.0 & $0.0(0)$ & 0.0 & $0.0(0)$ & 0.0 & $0.0(0)$ & 0.0 & $0.0(0)$ & 0.0 & $0.1(1)$ & $<0.1$ \\
\hline $\begin{array}{l}\text { Dunlin } \\
\text { Calidris alpina }\end{array}$ & $0.2(1)$ & $<0.1$ & $0.0(0)$ & 0.0 & $0.0(0)$ & 0.0 & $0.0(0)$ & 0.0 & $0.1(1)$ & $<0.1$ & $0.0(0)$ & 0.0 \\
\hline $\begin{array}{l}\text { Sanderling } \\
\text { Calidris alba }\end{array}$ & $0.0(0)$ & 0.0 & $0.0(0)$ & 0.0 & $0.0(0)$ & 0.0 & $0.0(0)$ & 0.0 & $0.0(0)$ & 0.0 & $0.2(2)$ & $<0.1$ \\
\hline $\begin{array}{l}\text { Kittiwake } \\
\text { Rissa tridactyla }\end{array}$ & $0.0(0)$ & 0.0 & $0.4(1)$ & 1.0 & $0.0(0)$ & 0.0 & $0.0(0)$ & 0.0 & $0.0(0)$ & 0.0 & $0.0(0)$ & 0.0 \\
\hline $\begin{array}{l}\text { Black-headed Gull } \\
\text { Chroicocephalus } \\
\text { ridibundus }\end{array}$ & $0.9(6)$ & 1.0 & $0.8(2)$ & 1.4 & $1.4(11)$ & 1.4 & $0.7(3)$ & 1.1 & $0.1(2)$ & 0.1 & $0.5(7)$ & 0.8 \\
\hline $\begin{array}{l}\text { Common Gull } \\
\text { Larus canus }\end{array}$ & $0.0(0)$ & 0.0 & $0.0(0)$ & 0.0 & $0.0(0)$ & 0.0 & $0.2(1)$ & 0.5 & $0.0(0)$ & 0.0 & $0.0(0)$ & 0.0 \\
\hline $\begin{array}{l}\text { Common Tern } \\
\text { Sterna hirundo }\end{array}$ & $0.2(1)$ & 0.1 & $0.0(0)$ & 0.0 & $0.0(0)$ & 0.0 & $0.0(0)$ & 0.0 & $0.1(1)$ & $<0.1$ & $0.0(0)$ & 0.0 \\
\hline $\begin{array}{l}\text { Arctic Tern } \\
\text { Sterna paradisaea }\end{array}$ & $0.0(0)$ & 0.0 & $0.0(0)$ & 0.0 & $0.3(2)$ & 0.1 & $0.0(0)$ & 0.0 & $0.0(0)$ & 0.0 & $0.1(1)$ & $<0.1$ \\
\hline $\begin{array}{l}\text { Barn Owl } \\
\text { Tyto alba }\end{array}$ & $0.0(0)$ & 0.0 & $0.8(2)$ & 1.4 & $0.0(0)$ & 0.0 & $0.2(1)$ & 0.4 & $0.3(5)$ & 0.3 & $0.2(2)$ & 0.2 \\
\hline $\begin{array}{l}\text { Tawny Owl } \\
\text { Strix aluco }\end{array}$ & $0.2(1)$ & 0.3 & $0.0(0)$ & 0.0 & $0.0(0)$ & 0.0 & $0.0(0)$ & 0.0 & $0.0(0)$ & 0.0 & $0.0(0)$ & 0.0 \\
\hline $\begin{array}{l}\text { Long-eared Owl } \\
\text { Asio otus }\end{array}$ & $0.0(0)$ & 0.0 & $0.0(0)$ & 0.0 & $0.0(0)$ & 0.0 & $0.0(0)$ & 0.0 & $0.0(0)$ & 0.0 & $0.1(1)$ & 0.1 \\
\hline $\begin{array}{l}\text { Short-eared Owl } \\
\text { Asio flammeus }\end{array}$ & $0.0(0)$ & 0.0 & $0.0(0)$ & 0.0 & $0.0(0)$ & 0.0 & $0.0(0)$ & 0.0 & $0.0(0)$ & 0.0 & $0.1(1)$ & 0.1 \\
\hline $\begin{array}{l}\text { Eurasian Sparrowhawk } \\
\text { Accipiter nisus }\end{array}$ & $0.0(0)$ & 0.0 & $0.0(0)$ & 0.0 & $0.4(3)$ & 0.3 & $0.2(1)$ & 0.3 & $0.1(2)$ & 0.1 & $0.0(0)$ & 0.0 \\
\hline $\begin{array}{l}\text { Kingfisher } \\
\text { Alcedo atthis }\end{array}$ & $0.0(0)$ & 0.0 & $0.0(0)$ & 0.0 & $0.0(0)$ & 0.0 & $0.0(0)$ & 0.0 & $0.0(0)$ & 0.0 & $0.1(1)$ & $<0.1$ \\
\hline $\begin{array}{l}\text { Great Spotted } \\
\text { Woodpecker } \\
\text { Dendrocopos major }\end{array}$ & $2.7(18)$ & 0.9 & $0.4(1)$ & 0.2 & $2.9(23)$ & 0.9 & $2.6(11)$ & 1.2 & $0.9(15)$ & 0.2 & $1.8(23)$ & 0.7 \\
\hline $\begin{array}{l}\text { Green Woodpecker } \\
\text { Picus viridis }\end{array}$ & $0.9(6)$ & 0.7 & $0.4(1)$ & 0.4 & $1.0(8)$ & 0.7 & $1.2(5)$ & 1.2 & $0.8(12)$ & 0.4 & $1.2(15)$ & 1.0 \\
\hline $\begin{array}{l}\text { Common Kestrel } \\
\text { Falco tinnunculus }\end{array}$ & $0.0(0)$ & 0.0 & $0.0(0)$ & 0.0 & $0.3(2)$ & 0.2 & $0.0(0)$ & 0.0 & 0.1 (1) & $<0.1$ & $0.1(1)$ & 0.1 \\
\hline $\begin{array}{l}\text { Merlin } \\
\text { Falco columbarius }\end{array}$ & $0.0(0)$ & 0.0 & $0.0(0)$ & 0.0 & $0.0(0)$ & 0.0 & $0.0(0)$ & 0.0 & $0.0(0)$ & 0.0 & $0.1(1)$ & 0.1 \\
\hline $\begin{array}{l}\text { Hobby } \\
\text { Falco subbuteo }\end{array}$ & $0.0(0)$ & 0.0 & $0.0(0)$ & 0.0 & $0.1(1)$ & 0.1 & $0.0(0)$ & 0.0 & $0.0(0)$ & 0.0 & $0.0(0)$ & 0.0 \\
\hline $\begin{array}{l}\text { Cockatiel } \\
\text { Nymphicus hollandicus }\end{array}$ & $0.0(0)$ & 0.0 & $0.0(0)$ & 0.0 & $0.0(0)$ & 0.0 & $0.0(0)$ & 0.0 & $0.1(2)$ & $<0.1$ & $0.2(2)$ & 0.1 \\
\hline $\begin{array}{l}\text { Budgerigar } \\
\text { Melopsittacus undulatus }\end{array}$ & $0.0(0)$ & 0.0 & $0.0(0)$ & 0.0 & $0.1(1)$ & $<0.1$ & $0.0(0)$ & 0.0 & $0.3(5)$ & 0.1 & $0.0(0)$ & 0.0 \\
\hline $\begin{array}{l}\text { Rosy-faced Lovebird } \\
\text { Agapornis roseicollis }\end{array}$ & $0.0(0)$ & 0.0 & $0.0(0)$ & 0.0 & $0.0(0)$ & 0.0 & $0.0(0)$ & 0.0 & $0.1(1)$ & $<0.1$ & $0.0(0)$ & 0.0 \\
\hline $\begin{array}{l}\text { Jay } \\
\text { Garrulus glandarius }\end{array}$ & $1.4(9)$ & 0.9 & $0.4(1)$ & 0.4 & $1.6(13)$ & 1.0 & $1.4(6)$ & 1.3 & $0.9(14)$ & 0.4 & $1.6(21)$ & 1.3 \\
\hline
\end{tabular}




\begin{tabular}{|c|c|c|c|c|c|c|c|c|c|c|c|c|}
\hline \multirow{3}{*}{ Species } & \multicolumn{4}{|c|}{ Central Wales } & \multicolumn{4}{|c|}{ Brecon Beacons } & \multicolumn{4}{|c|}{ South Wales } \\
\hline & \multicolumn{2}{|c|}{ Summer } & \multicolumn{2}{|c|}{ Winter } & \multicolumn{2}{|c|}{ Summer } & \multicolumn{2}{|c|}{ Winter } & \multicolumn{2}{|c|}{ Summer } & \multicolumn{2}{|c|}{ Winter } \\
\hline & $\% \mathrm{~N}(\mathrm{~N})$ & $\begin{array}{c}\% \\
\text { wt. }\end{array}$ & $\% \mathrm{~N}(\mathrm{~N})$ & $\begin{array}{l}\% \\
\text { wt. }\end{array}$ & $\% N(N)$ & $\begin{array}{c}\% \\
\text { wt. }\end{array}$ & $\% \mathrm{~N}(\mathrm{~N})$ & \begin{tabular}{|c|}
$\%$ \\
wt.
\end{tabular} & $\% \mathbf{N}(\mathbf{N})$ & \begin{tabular}{|c|}
$\%$ \\
wt.
\end{tabular} & $\% \mathrm{~N}(\mathrm{~N})$ & $\begin{array}{l}\% \\
\text { wt. }\end{array}$ \\
\hline $\begin{array}{l}\text { Eurasian Magpie } \\
\text { Pica pica }\end{array}$ & $3.3(22)$ & 2.9 & $1.2(3)$ & 1.6 & $1.3(10)$ & 1.0 & $4.8(20)$ & 5.9 & $1.1(17)$ & 0.7 & $3.6(46)$ & 3.8 \\
\hline $\begin{array}{l}\text { Jackdaw } \\
\text { Coloeus monedula }\end{array}$ & $\begin{array}{l}12.0 \\
(79) \\
\end{array}$ & 10.7 & $\begin{array}{l}11.6 \\
(30) \\
\end{array}$ & 16.6 & $\begin{array}{l}11.3 \\
(90) \\
\end{array}$ & 9.3 & $\begin{array}{l}17.1 \\
(71)\end{array}$ & 21.4 & $\begin{array}{c}7.2 \\
(114)\end{array}$ & 5.0 & $\begin{array}{r}13.2 \\
(168) \\
\end{array}$ & $\mid$\begin{tabular}{|l}
$\mid$ \\
\end{tabular} \\
\hline $\begin{array}{l}\text { Rook } \\
\text { Corvus frugilegus }\end{array}$ & $2(21)$ & 3.9 & $0.4(1)$ & 0.8 & $0.4(3)$ & 0.4 & $1.0(4)$ & 1.6 & $0.0(0)$ & 0.0 & $0.0(0)$ & 0.0 \\
\hline $\begin{array}{l}\text { Carrion Crow } \\
\text { Corvus corone }\end{array}$ & $1.1(7)$ & 2.1 & $0.4(1)$ & 1.2 & $1.0(8)$ & 1.8 & $1.4(6)$ & 4.0 & $0.3(4)$ & 0.4 & $0.5(7)$ & 1.3 \\
\hline $\begin{array}{l}\text { Coal Tit } \\
\text { Periparus ater }\end{array}$ & $0.3(2)$ & $<0.1$ & $1.9(5)$ & 0.1 & $0.0(0)$ & 0.0 & $0.0(0)$ & 0.0 & $0.1(1)$ & $<0.1$ & $0.2(3)$ & $<0.1$ \\
\hline $\begin{array}{l}\text { Great Tit } \\
\text { Parus major }\end{array}$ & $0.0(0)$ & 0.0 & $0.0(0)$ & 0.0 & $0.3(2)$ & $<0.1$ & $0.0(0)$ & 0.0 & $0.0(0)$ & 0.0 & $0.2(2)$ & $<0.1$ \\
\hline $\begin{array}{l}\text { Blue Tit } \\
\text { Cyanistes caer }\end{array}$ & $0.3(2)$ & $<0.1$ & $0.0(0)$ & 0.0 & $0.0(0)$ & 0.0 & $0.0(0)$ & 0.0 & $0.0(0)$ & 0.0 & $0.0(0)$ & 0.0 \\
\hline $\begin{array}{l}\text { Skylark } \\
\text { Alauda arvensis }\end{array}$ & $1.5(10)$ & 0.2 & $0.8(2)$ & 0.2 & $2.1(17)$ & 0.3 & $0.7(3)$ & 0.2 & $1.5(24)$ & 0.2 & $0.7(9)$ & 0.1 \\
\hline $\begin{array}{l}\text { Sand Martin } \\
\text { Riparia riparia }\end{array}$ & $0.2(1)$ & $<0.1$ & $0.0(0)$ & 0.0 & $0.0(0)$ & 0.0 & $0.0(0)$ & 0.0 & $0.0(0)$ & 0.0 & $0.0(0)$ & 0.0 \\
\hline $\begin{array}{l}\text { Barn Swallow } \\
\text { Hirundo rustica }\end{array}$ & $0.6(4)$ & $<0.1$ & $0.0(0)$ & 0.0 & $0.0(0)$ & 0.0 & $0.0(0)$ & 0.0 & $0.3(5)$ & $<0.1$ & $0.1(1)$ & $<0.1$ \\
\hline $\begin{array}{l}\text { House Martin } \\
\text { Delichon urbicun }\end{array}$ & $0.0(0)$ & 0.0 & $0.0(0)$ & 0.0 & $0.1(1)$ & $<0.1$ & $0.0(0)$ & 0.0 & $0.1(2)$ & $<0.1$ & $0.0(0)$ & 0.0 \\
\hline $\begin{array}{l}\text { Willow Warbler } \\
\text { Phylloscopus trochilus }\end{array}$ & $0.2(1)$ & $<0.1$ & $0.0(0)$ & 0.0 & $0.4(3)$ & $<0.1$ & $0.0(0)$ & 0.0 & $0.0(0)$ & $\begin{array}{l}0.0 \\
\end{array}$ & $0.0(0)$ & 0.0 \\
\hline $\begin{array}{l}\text { Goldcrest } \\
\text { Regulus regulus }\end{array}$ & $0.0(0)$ & 0.0 & $0.0(0)$ & 0.0 & $0.0(0)$ & 0.0 & $0.0(0)$ & 0.0 & $0.1(1)$ & $<0.1$ & $0.2(2)$ & $<0.1$ \\
\hline $\begin{array}{l}\text { Wren } \\
\text { Troglodytes troglodytes }\end{array}$ & $0.0(0)$ & 0.0 & $0.0(0)$ & 0.0 & $0.0(0)$ & 0.0 & $0.0(0)$ & 0.0 & $0.1(2)$ & $<0.1$ & $0.2(2)$ & $<0.1$ \\
\hline $\begin{array}{l}\text { Nuthatch } \\
\text { Sitta europaea }\end{array}$ & $0.0(0)$ & 0.0 & $0.0(0)$ & 0.0 & $0.0(0)$ & 0.0 & $0.0(0)$ & 0.0 & $0.0(0)$ & 0.0 & $0.1(1)$ & $<0.1$ \\
\hline $\begin{array}{l}\text { Treecreeper } \\
\text { Certhia familiaris }\end{array}$ & $0.0(0)$ & 0.0 & $0.0(0)$ & 0.0 & $0.0(0)$ & 0.0 & $0.0(0)$ & 0.0 & $0.1(1)$ & $<0.1$ & $0.0(0)$ & 0.0 \\
\hline $\begin{array}{l}\text { Starling } \\
\text { Sturnus vulgaris }\end{array}$ & $\begin{array}{l}7.9 \\
(52)\end{array}$ & 2.6 & $\begin{array}{l}12.4 \\
(32)\end{array}$ & 6.5 & $\begin{array}{l}8.4 \\
(67)\end{array}$ & 2.6 & $\begin{array}{l}9.1 \\
(38)\end{array}$ & 4.2 & $\begin{array}{l}6.9 \\
(109)\end{array}$ & \begin{tabular}{|l|}
1.8 \\
\end{tabular} & $\begin{array}{l}6.6 \\
(84)\end{array}$ & 2,7 \\
\hline $\begin{array}{l}\text { Ring Ouzel } \\
\text { Turdus torquatus }\end{array}$ & $0.2(1)$ & 0.1 & $0.0(0)$ & 0.0 & $0.4(3)$ & 0.2 & $0.2(1)$ & 0.2 & $0.1(1)$ & $<0.1$ & $0.1(1)$ & $<0.1$ \\
\hline $\begin{array}{l}\text { Blackbird } \\
\text { Turdus merula }\end{array}$ & $\begin{array}{l}5.8 \\
(38)\end{array}$ & 2.3 & $\begin{array}{l}6.9 \\
(18) \\
\end{array}$ & 4.4 & $4.8(38)$ & 1.8 & $\begin{array}{l}5.0 \\
(21)\end{array}$ & 2.8 & $3.3(53)$ & \begin{tabular}{|l}
1.0 \\
|
\end{tabular} & $4.2(54)$ & 2.1 \\
\hline $\begin{array}{l}\text { Fieldfare } \\
\text { Turdus pilaris }\end{array}$ & $1.7(11)$ & 0.7 & $\begin{array}{l}12.4 \\
(32)\end{array}$ & 8.5 & $0.3(2)$ & 0.1 & $\begin{array}{l}9.9 \\
(41) \\
\end{array}$ & 5.9 & $0.2(3)$ & \begin{tabular}{|l|}
0.1 \\
\end{tabular} & $\begin{array}{l}7.2 \\
(92) \\
\end{array}$ & 3.8 \\
\hline $\begin{array}{l}\text { Redwing } \\
\text { Turdus iliacus }\end{array}$ & $0.8(5)$ & 0.2 & $\begin{array}{l}20.1 \\
(52) \\
\end{array}$ & 8.2 & $0.6(5)$ & 0.1 & $\begin{array}{l}13.9 \\
(58)\end{array}$ & 5.0 & $0.2(2)$ & $<0.1$ & $\begin{array}{c}12.9 \\
(164)\end{array}$ & 4.0 \\
\hline $\begin{array}{l}\text { Song Thrush } \\
\text { Turdus philomelos }\end{array}$ & $1.8(12)$ & 0.6 & $2.3(6)$ & 1.2 & $2.3(18)$ & 0.7 & $2.9(12)$ & 1.3 & $1.1(18)$ & 0.3 & $2.3(29)$ & 0.9 \\
\hline $\begin{array}{l}\text { Mistle Thrush } \\
\text { Turdus viscivorus }\end{array}$ & $\begin{array}{l}5.8 \\
(38)\end{array}$ & 2.8 & $3.5(9)$ & 2.7 & $3.8(30)$ & 1.7 & $2.6(11)$ & 1.8 & $1.0(16)$ & \begin{tabular}{|l|}
0.4 \\
\end{tabular} & $1.6(21)$ & 1.3 \\
\hline $\begin{array}{l}\text { Robin } \\
\text { Erithacus rubecula }\end{array}$ & $0.2(1)$ & $<0.1$ & $0.0(0)$ & 0.0 & $0.1(1)$ & $<0.1$ & $0.2(1)$ & $<0.1$ & $0.1(1)$ & $<0.1$ & $0.1(1)$ & $<0.1$ \\
\hline $\begin{array}{l}\text { Black Redstart } \\
\text { Phoenicurus ochruros }\end{array}$ & $0.0(0)$ & 0.0 & $0.0(0)$ & 0.0 & $0.0(0)$ & 0.0 & $0.0(0)$ & 0.0 & $0.0(0)$ & 0.0 & $0.1(1)$ & $<0.1$ \\
\hline $\begin{array}{l}\text { Redstart } \\
\text { Phoenicurus phoenicurus }\end{array}$ & $0.0(0)$ & 0.0 & $0.0(0)$ & 0.0 & $0.1(1)$ & $<0.1$ & $0.0(0)$ & 0.0 & $0.1(1)$ & $<0.1$ & $0.0(0)$ & 0.0 \\
\hline
\end{tabular}




\begin{tabular}{|c|c|c|c|c|c|c|c|c|c|c|c|c|}
\hline \multirow{3}{*}{ Species } & \multicolumn{4}{|c|}{ Central Wales } & \multicolumn{4}{|c|}{ Brecon Beacons } & \multicolumn{4}{|c|}{ South Wales } \\
\hline & \multicolumn{2}{|c|}{ Summer } & \multicolumn{2}{|c|}{ Winter } & \multicolumn{2}{|c|}{ Summer } & \multicolumn{2}{|c|}{ Winter } & \multicolumn{2}{|c|}{ Summer } & \multicolumn{2}{|c|}{ Winter } \\
\hline & $\% \mathbf{N}(\mathbf{N})$ & \begin{tabular}{c|}
$\%$ \\
wt.
\end{tabular} & $\% \mathrm{~N}(\mathrm{~N})$ & $\begin{array}{r}\% \\
\text { wt. }\end{array}$ & $\% \mathbf{N}(\mathbf{N})$ & $\begin{array}{c}\% \\
\text { wt. } \\
\end{array}$ & $\% \mathrm{~N}(\mathrm{~N})$ & $\begin{array}{c}\% \\
\text { wt. }\end{array}$ & $\% \mathbf{N}(\mathbf{N})$ & $\begin{array}{c}\% \\
\text { wt. }\end{array}$ & $\% \mathbf{N}(\mathbf{N})$ & $\begin{array}{r}\% \\
\text { wt. }\end{array}$ \\
\hline $\begin{array}{l}\text { Whinchat } \\
\text { Saxicola rubetra }\end{array}$ & $0.0(0)$ & 0.0 & $0.0(0)$ & 0.0 & $0.1(1)$ & $<0.1$ & $0.0(0)$ & 0.0 & $0.0(0)$ & 0.0 & $0.0(0)$ & 0.0 \\
\hline $\begin{array}{l}\text { Stonechat } \\
\text { Saxicola rubicola }\end{array}$ & $0.2(1)$ & $<0.1$ & $0.0(0)$ & 0.0 & $0.0(0)$ & 0.0 & $0.0(0)$ & 0.0 & $0.1(1)$ & $<0.1$ & $0.1(1)$ & $<0.1$ \\
\hline $\begin{array}{l}\text { Northern Wheatear } \\
\text { Oenanthe oenanthe }\end{array}$ & $0.9(6)$ & 0.1 & $0.0(0)$ & 0.0 & $0.9(7)$ & 0.1 & $0.0(0)$ & 0.0 & $0.4(6)$ & $<0.1$ & $0.1(1)$ & $<0.1$ \\
\hline $\begin{array}{l}\text { Dipper } \\
\text { Cinclus cinclus }\end{array}$ & $0.0(0)$ & 0.0 & $0.0(0)$ & 0.0 & $0.0(0)$ & 0.0 & $0.2(1)$ & 0.1 & $0.0(0)$ & 0.0 & $0.0(0)$ & 0.0 \\
\hline $\begin{array}{l}\text { House Sparrow } \\
\text { Passer domesticus }\end{array}$ & $0.0(0)$ & 0.0 & $0.0(0)$ & 0.0 & $0.0(0)$ & 0.0 & $0.0(0)$ & 0.0 & $0.0(0)$ & 0.0 & $0.1(1)$ & $<0.1$ \\
\hline $\begin{array}{l}\text { Dunnock } \\
\text { Prunella modularis }\end{array}$ & $0.0(0)$ & 0.0 & $0.4(1)$ & 0.1 & $0.0(0)$ & 0.0 & $0.0(0)$ & 0.0 & $0.0(0)$ & 0.0 & $0.0(0)$ & 0.0 \\
\hline $\begin{array}{l}\text { White Wagtail } \\
\text { Motacilla alba }\end{array}$ & $0.3(2)$ & $<0.1$ & $0.0(0)$ & 0.0 & $0.0(0)$ & 0.0 & $0.0(0)$ & 0.0 & $0.2(3)$ & $<0.1$ & $0.1(1)$ & $<0.1$ \\
\hline $\begin{array}{l}\text { Meadow Pipit } \\
\text { Anthus pratensis }\end{array}$ & $1.4(9)$ & 0.1 & $1.2(3)$ & 0.1 & $3.4(27)$ & 0.2 & $0.5(2)$ & 0.1 & $1.6(25)$ & 0.1 & $1.6(21)$ & 0.2 \\
\hline $\begin{array}{l}\text { Rock Pipit } \\
\text { Anthus petrosus }\end{array}$ & $0.0(0)$ & 0.0 & $0.0(0)$ & 0.0 & $0.0(0)$ & 0.0 & $0.0(0)$ & 0.0 & $0.1(1)$ & $<0.1$ & $0.0(0)$ & 0.0 \\
\hline $\begin{array}{l}\text { Chaffinch } \\
\text { Fringilla coelebs }\end{array}$ & $2.0(13)$ & 0.2 & $1.5(4)$ & 0.2 & $0.8(6)$ & 0.1 & $1.4(6)$ & 0.2 & $1.6(25)$ & 0.1 & $2.6(33)$ & 0.3 \\
\hline $\begin{array}{l}\text { Brambling } \\
\text { Fringilla montifringilla }\end{array}$ & $0.0(0)$ & 0.0 & $0.0(0)$ & 0.0 & $0.0(0)$ & 0.0 & $0.0(0)$ & 0.0 & $0.0(0)$ & 0.0 & $0.1(1)$ & $<0.1$ \\
\hline $\begin{array}{l}\text { Greenfinch } \\
\text { Carduelis chloris }\end{array}$ & $0.2(1)$ & 0.1 & $0.4(1)$ & 0.2 & $0.1(1)$ & $<0.1$ & $0.0(0)$ & 0.0 & $0.1(1)$ & $<0.1$ & $0.0(0)$ & 0.0 \\
\hline $\begin{array}{l}\text { Siskin } \\
\text { Carduelis spinus }\end{array}$ & $0.2(1)$ & $<0.1$ & $0.8(2)$ & 0.1 & $0.0(0)$ & 0.0 & $0.2(1)$ & $<0.1$ & $0.1(2)$ & $<0.1$ & $0.4(5)$ & $<0.1$ \\
\hline $\begin{array}{l}\text { Goldfinch } \\
\text { Carduelis carduelis }\end{array}$ & $0.3(2)$ & $<0.1$ & $0.4(1)$ & $<0.1$ & $0.0(0)$ & 0.0 & $0.2(1)$ & $<0.1$ & $0.5(8)$ & $<0.1$ & $0.3(4)$ & $<0.1$ \\
\hline $\begin{array}{l}\text { Common Redpoll } \\
\text { Carduelis flammea }\end{array}$ & $0.0(0)$ & 0.0 & $0.0(0)$ & 0.0 & $0.1(1)$ & $<0.1$ & $0.0(0)$ & 0.0 & $0.1(1)$ & $<0.1$ & $0.0(0)$ & 0.0 \\
\hline $\begin{array}{l}\text { Linnet } \\
\text { Carduelis cannabina }\end{array}$ & $0.2(1)$ & $<0.1$ & $0.0(0)$ & 0.0 & $0.3(2)$ & $<0.1$ & $0.0(0)$ & 0.0 & $0.2(3)$ & $<0.1$ & $0.2(2)$ & $<0.1$ \\
\hline $\begin{array}{l}\text { Common Crossbill } \\
\text { Loxia curvirostra }\end{array}$ & $0.0(0)$ & 0.0 & $0.0(0)$ & 0.0 & $0.0(0)$ & 0.0 & $0.0(0)$ & 0.0 & 0.1 (1) & $<0.1$ & $0.1(1)$ & $<0.1$ \\
\hline $\begin{array}{l}\text { Bullfinch } \\
\text { Pyrrhula pyrrhula }\end{array}$ & $0.3(2)$ & $<0.1$ & $0.4(1)$ & 0.1 & $0.0(0)$ & 0.0 & $0.2(1)$ & $<0.1$ & $0.1(1)$ & $<0.1$ & $0.2(3)$ & $<0.1$ \\
\hline $\begin{array}{l}\text { Reed Bunting } \\
\text { Emberiza schoeniclus }\end{array}$ & $0.2(1)$ & $<0.1$ & $0.0(0)$ & 0.0 & $0.3(2)$ & $<0.1$ & $0.0(0)$ & 0.0 & $0.2(3)$ & $<0.1$ & $0.2(3)$ & $<0.1$ \\
\hline $\begin{array}{l}\text { Snow Bunting } \\
\text { Plectrophenax nivalis }\end{array}$ & $0.0(0)$ & 0.0 & $0.0(0)$ & 0.0 & $0.0(0)$ & 0.0 & $0.0(0)$ & 0.0 & $0.0(0)$ & 0.0 & $0.1(1)$ & $<0.1$ \\
\hline
\end{tabular}

